Article

\title{
An Approach to Delineate Potential Groundwater Zones in Kilinochchi District, Sri Lanka, Using GIS Techniques
}

\author{
Vyddiyaratnam Pathmanandakumar ${ }^{1}$, Nadarajapillai Thasarathan ${ }^{2 *}$ and Manjula Ranagalage ${ }^{3,}$
}

1 Department of Geography, Faculty of Arts \& Culture, Eastern University, Chenkalady 30350, Sri Lanka; pathmanandakumarv@esn.ac.lk

2 Department of Geography, Faculty of Arts, University of Jaffna, Thirunelvely, Jaffna 40000, Sri Lanka; nthasarathan@jfn.ac.lk

3 Department of Environmental Management, Faculty of Social Sciences \& Humanities, Rajarata University of Sri Lanka, Mihintale 50300, Sri Lanka; manjularanagalage@gmail.com

* Correspondence: nthasarathan@jfn.ac.lk

\begin{abstract}
:
The scarcity of surface water resources in the dry season in the Kilinochchi district increases the demand for freshwater. Therefore, the existing groundwater resources should be managed to overcome the situation. Several authors worldwide have published studies on the delineation of potential groundwater zone. However, only a few studies addressed the delineation of potential groundwater zones in the Kilinochchi district. This study aims to delineate potential groundwater zones in Kilinochchi, Sri Lanka using integrated Remote Sensing, Geographic Information Systems, and Analytic Hierarchy Process techniques. Groundwater potential zones are demarcated for the Kilinochchi district by overlaying thematic layers: geology, geomorphology, land use/land cover, soil types, drainage density, slope, lineament, and rainfall. Saaty's scale was applied to the assigned weights of the chosen thematic layers and their features. The thematic layers were integrated into a Geographic Information System, and a weighted overlay analysis is carried out to delineate groundwater zones. Thus the resultant map is categorized into five different potential zones: very low, low, moderate, high, and very high. It was found that the very high groundwater potential zone is mainly found in the north-eastern part of the study area covering $111.26 \mathrm{~km}^{2}$. The upper north-western, middle, and eastern parts of the study area fall within the high groundwater potential zone covering about $507.74 \mathrm{~km}^{2}$. The moderate groundwater potential zones $\left(309.89 \mathrm{~km}^{2}\right)$ mainly occurred in the western part, and the extreme west part of the study area falls under low $\left(207.78 \mathrm{~km}^{2}\right)$ and very low $\left(59.12 \mathrm{~km}^{2}\right)$ zones. The groundwater potential map was validated with the existing seventy-nine wells, which indicated a good prediction accuracy of $81.8 \%$. This research will help policymakers better manage the Kilinochchi district's groundwater resources and gives scope for further research into groundwater exploration in the area.
\end{abstract}

Keywords: Remote sensing, GIS, AHP, Groundwater potential zone, Weighted overlay analysis, Kilinochchi

\section{Introduction}

Water is one of the fundamental means of elements to sustain life on Earth. It has become a necessary resource in the development of society from the beginning of human civilization [1]. Water plays a significant part in our everyday lives. Water covers around $70 \%$ of the Earth's surface, in which $97 \%$ is saline by nature, and the rest of the $3 \%$ remains as freshwater. Polar ice sheets and ice in glaciers cover a major part of the freshwater. Lakes and rivers contain less than $1 \%$ freshwater, whereas 30\% of the freshwater is saved as groundwater [2]. Groundwater or subsurface water is "a term used to denote all the 
waters found beneath the ground surface" [3]. Groundwater is defined as "water in a saturated zone, filling the pore spaces among mineral grains or cracks and fractured rocks in a rock mass" [4]. Naturally, the water from rain and snow infiltrates through soil or the pore spaces of underlying rocks to replenish the groundwater $[3,4]$. Therefore, climate, characteristics of surface and subsurface, and their relationship with hydrology decide the occurrence and distribution of groundwater [3]. About one-third of the world's population utilizes groundwater for drinking purposes [5], and demand for groundwater increases worldwide due to many factors such as population growth, advanced irrigation practice, industrial usages, etc. [6-8]. Notably, there is tremendous pressure on groundwater in developing countries [2].

Integrated Geographic Information System (GIS) and Remote Sensing (RS) with Analytical Hierarchy Process (AHP) prove that it is a handy tool for delineation of groundwater potential zones by reducing time and cost [1,5,9-13]. Also, several variables are often considered in the integrated approach to reduce inaccuracy and human error, such as lithology, linearity, drainage density, slope, geomorphology, erosion, patterns of land use, and soils [5,9,10,12,14]. Researchers adopt various techniques for delineation potential groundwater zones such as statistical method, influence factor (IMF), groundwater modelling, and the combination of GIS, RS with AHP [5,6,9,12,14]. Recently, remote sensing and GIS coupled with AHP techniques have been adopted as a standard methodology for delineating potential groundwater zones in semi-arid areas $[1,2,5,6,9,15,16]$.

Agriculture is vital to the Sri Lankan economy. In Sri Lanka, water availability and demand for it vary spatially and temporally. Water shortage is the foremost issue in the country's dry zone, where there is a significant demand for water to irrigate $85 \%$ of the land to boost agricultural productivity $[17,18]$. Groundwater is the primary source of fresh water for rural communities in the dry zone of Sri Lanka. The Kilinochchi district falls within the dry zone of Sri Lanka and receives rainfall from North-East Monsoon and intermonsoon, which replenishes the groundwater resources [18]. Population in Kilinochchi district has increased from 23,625 in 2009 to 146,199 in 2020 [19]. With decreasing rainfall and an increasing population in the dry zone, there is a significant demand for water for irrigation and other livelihood needs, which mandates sustainable groundwater use in the dry zone [18]. The seasonal water resource availability per unit area in the study area is less than $0.1 \mathrm{~m}$. With present irrigation efficiency, more portions of the dry zone of Sri Lanka may experience water scarcity by 2025 [18,20]. Sustainable development of groundwater resources is one of the best options for supporting dry-zone populations to improve their livelihoods by increasing agricultural productivity without depleting groundwater reserves. Groundwater is the primary source of drinking and agricultural practice in the Kilinochchi district. It is indiscriminately extracted in many parts of the district as surface water is insufficient to satisfy the demand. Therefore, the delineation of potential groundwater zones by an appropriate modelling approach is necessary to address the water scarcity problem of the drought-prone district. Very few studies have been conducted on water issues in the Kilinochchi district [18]. In light of this aspect, the present study aims to delineate potential groundwater zones in Kilinochchi, Sri Lanka using integrated RS, GIS, and AHP techniques.

\section{Materials and Methods}

\subsection{Study area}

Kilinochchi district is situated in the Northern Province of Sri Lanka and bounded in North and East by Jaffna district, and on the South by Mullaitivu district and on the East by the Indian Ocean. It lies between the North latitudes $9^{\circ} 12^{\prime} 30^{\prime \prime}$ and $9^{\circ} 41^{\prime} 00^{\prime \prime}$ and East longitude $79^{\circ} 58^{\prime} 30^{\prime \prime}$ and $80^{\circ} 37^{\prime} 30^{\prime \prime}$ and spread over $1237.11 \mathrm{Km}^{2}$ (Figure. 1). The study area falls within the dry zone (annual average rainfall of $<1750 \mathrm{~mm}$ ) that extends over twothirds of Sri Lanka, covering the north-western, north-central, northern, north-eastern, 
eastern, and south-eastern regions of the country [21]. The average annual rainfall of the district is $1520.57 \mathrm{~mm}$. The monthly mean temperature is between $25^{\circ} \mathrm{C}$ and $30^{\circ} \mathrm{C}$ [22]. Geologically, the major part of the Kilinochchi district constitutes alluvial and lagoonal clay, silt sand, whereas the western parts represent Red earth and red and brown sand. Jaffna limestone (Minihagalkanda Beds), Undifferentiated Vijayan gneiss with trend lines, Beach, and dune sand are also seen. The elevation of the district ranges from $49.63 \mathrm{~m}$ in the southern part to less than $6.6 \mathrm{~m}$ in the northern region. The topography of the area exhibits relatively flat terrain covering a larger part of the coastal zone. The Kilinochchi district is occupied with seasonal rivers and streams, which flow Northwards to the Indian Ocean. The soil type of the district is dominated by Red-Yellow Latosols and followed by Alluvial soils of variable texture, Alkali, and saline soils of varying texture (Solodized Solonetz and Solonchaks), Sand Regosols on the recent beach and dune sands and Red-Yellow Podzolic soils.

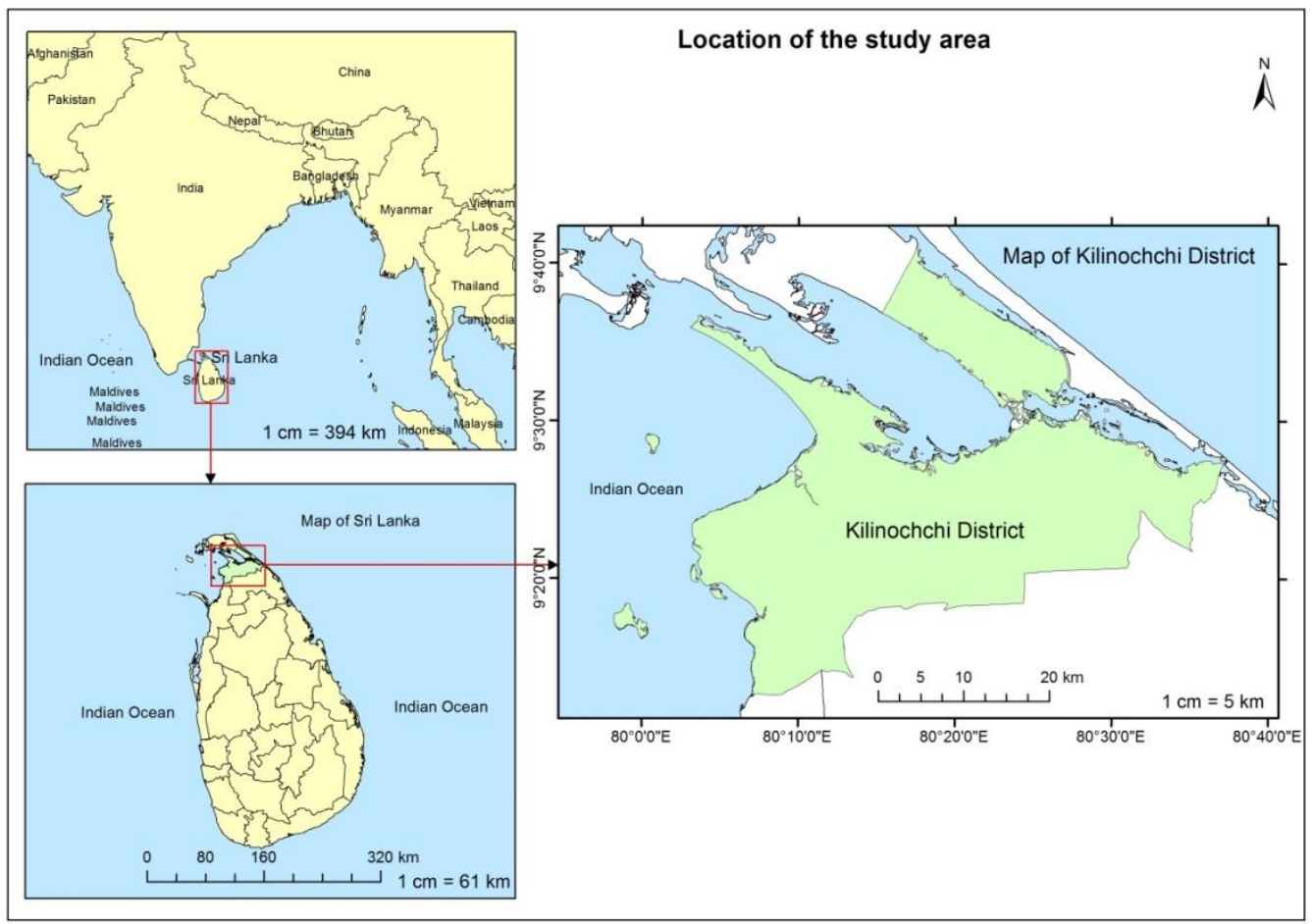

Figureure 1: Location map of the study area (Kilinochchi district)

\subsection{Methods}

The overall concept of the study included integrating eight thematic layers of geology, geomorphology, soil, drainage, slope, land use \& land cover, rainfall, lineament $[13,14,23]$ processed by weighted overlay analysis using ArcGIS 10.4.1 to generate potential groundwater zone. The potential groundwater zones have been delineated using integrated RS, GIS, and AHP techniques. Required data were gathered from various government agencies, field surveys, and publicly available satellite imagery on the United States Geological Survey (USGS) Earth Explorer website. Thematic layers preparation consists of digital image processing, digitizing existing maps, and field data. All data are geo-rectified and projected to GCS WGS 84 UTM zone 44 North for easy handling in ArcGIS 10.4.1. The present analysis has been based on several types of data from different sources. Table 1 provides a detailed summary of the data sources. Drainage density map and lineament density map were produced using a line density analysis tool in ArcGIS 10.4.1.

Advanced Spaceborne Thermal Emission and Reflection Radiometer - Global Digital Elevation Model (ASTER- GDEM) with 30m resolution was used to generate a slope map, 
drainage density map and lineament map. Those maps were then reclassified to generate the map. The rainfall data were spatially interpolated with Inverse Distance Weighted (IDW) to obtain the rainfall distribution map. IDW interpolation uses a weighted collection of sample points to calculate cell values. Its general concept is that the attribute value of an unsampled location is the weighted average of known values in the surrounding area [24]. The idea is that sampled points closer to the unsampled point are more comparable in their value than those further away. In this study, the deterministic model of the IDW method is used to interpolate spatial data based on the concept of distance weighting. Long-term observed rainfall data were required for analysis in utilizing IDW to interpolate spatial rainfall [25]. As a result, this study used average rainfall data from 1990 to 2020 over 30 years. It can predict unknown spatial rainfall data using available data from nearby places [25]. An accuracy assessment of Land Use and Land Cover (LULC) was conducted to assess the accuracy level of the resulting classes. A stratified random sampling method was applied to generate 250 random points, and Google Earth imagery was used as the ground truth reference to examine the random points. The date of the Google Earth imagery was concurrent with the LULC map. A confusion matrix was applied to compute the user's accuracy, producer's accuracy, and overall accuracy for the LULC map with the data obtained from comparisons between the reference and actual points. The accuracy was found to be $88 \%$ overall classification accuracy and 0.84 overall kappa coefficient. The primary advantages of using remote sensing and GIS techniques for delineating potential groundwater zones are cost-effective and time savings, fast retrieval of information on groundwater occurrence, and identification of potential areas for further groundwater exploration.

Table 1: List of data layers and their sources

\begin{tabular}{|c|c|c|c|}
\hline Elements & Data & $\begin{array}{c}\text { Spatial } \\
\text { Resolution }\end{array}$ & Source \\
\hline Base Map & $\begin{array}{l}\text { Topographic sheet } \\
\text { No. } 04,05,07,08,09\end{array}$ & $1: 50,000$ & $\begin{array}{l}\text { Survey Department of } \\
\text { Sri Lanka }\end{array}$ \\
\hline Geology Map & $\begin{array}{l}\text { Geological Map of } \\
\text { Sri Lanka }\end{array}$ & 1:100,000 & $\begin{array}{l}\text { Geological Survey and } \\
\text { Mines Bureau of Sri } \\
\text { Lanka }\end{array}$ \\
\hline $\begin{array}{l}\text { Geomorphology } \\
\text { Map }\end{array}$ & $\begin{array}{l}\text { Geomorphological } \\
\text { Map of Sri Lanka }\end{array}$ & $1: 100,000$ & $\begin{array}{l}\text { Geological Survey and } \\
\text { Mines Bureau of Sri } \\
\text { Lanka }\end{array}$ \\
\hline Soil Map & $\begin{array}{l}\text { Soil Map of Sri } \\
\text { Lanka }\end{array}$ & $1: 100,000$ & $\begin{array}{l}\text { Geological Survey and } \\
\text { Mines Bureau of Sri } \\
\text { Lanka }\end{array}$ \\
\hline Slope Map & ASTER GDEM & $30 \mathrm{~m}$ & USGS \\
\hline $\begin{array}{l}\text { Map of drainage } \\
\text { density }\end{array}$ & ASTER GDEM & $30 \mathrm{~m}$ & USGS \\
\hline Lineament Map & ASTER GDEM & $30 \mathrm{~m}$ & USGS \\
\hline $\begin{array}{l}\text { Land Use \& } \\
\text { Land Cover }\end{array}$ & Sentinel-2 & $10 \mathrm{~m}$ & USGS \\
\hline Map of Rainfall & Rainfall data & & $\begin{array}{l}\text { The Statistical } \\
\text { Handbook } 2019 \text { of } \\
\text { District Secretariat, } \\
\text { Kilinochchi, Sri Lanka }\end{array}$ \\
\hline
\end{tabular}

The key factors influencing the groundwater potential are geology, geomorphology, soil, drainage density, slope, land use \& land cover, rainfall, and lineament density $[1,9,10,13,15,16,21,26]$. Therefore, eight thematic layers (parameters) such as geology $(\mathrm{Ge})$, geomorphology $(\mathrm{Gm})$ land use/land cover (LuLc), soil types $(\mathrm{St})$, drainage density $(\mathrm{Dd})$, 
Slope (Sp), lineament (Lt), and rainfall (Rf) are considered to delineate the potential groundwater zones in the Kilinochchi district. Based on previous literature studies and expert opinion, Saaty's scale was applied to the assigned weights of the chosen eight thematic layers and their features with respect to their influence on groundwater storage (Table 1). The highest and lowest weights were allocated to the themes of the strong groundwater potential and weakest groundwater potential, respectively $[3,6,12,13,26,27]$.

The methodology adopted for the present study is shown in Figure. 2. These layers are geo-referenced and vectorized from various spatial data sources such as the topographic sheet scaled 1:50,000 of Survey Department of Sri Lanka, Geological Map of Sri Lanka, Geomorphological Map of Sri Lanka, Soil Map of Sri Lanka of Geological Survey and Mines Bureau of Sri Lanka, Satellite images (ASTER GDEM and Sentinel-2) of USGS. These thematic layers were converted into a raster format of $30 \mathrm{~m}$ resolution and subjected to weighted overlay analysis in Arc GIS 10.4 environment. Field data have been used to verify the accuracy of the groundwater potential map to ensure that the specified areas meet the conditions on the field.

\subsubsection{Assignment of weight and Weights Normalization}

The multi-criteria decision analysis (MCDA) is a generally recognized and highly appropriate technique for complex decision-making problems. Standardized weights were allocated by using Saaty's (1980). The AHP helps to find out the weight of criterion by pair-wise comparison [28]. The AHP is a concept of measurement by pair-wise comparison matrix (PCM) and is based on the judgment of experts to derive priority weights [26]. The worldwide academic network progressed the integrated GIS and AHP technique to investigate complex spatial issues $[1,9,11,12,15,26,29]$. PCM for thematic layer viz. geology, geomorphology, soil, drainage density, slope, land use \& land cover, rainfall, and lineament density is calculated based on Saaty's 1-9 scale weights. Field experience and expertise are used to assess the value of the Saaty's scale of each thematic layer. The weights were given according to their potential for groundwater recharge. The high weight is assigned to the themes of good groundwater potential, and the least weight is assigned to poor groundwater potential.

Table 2: Pair-wise comparison matrix for the AHP process

\begin{tabular}{lllllllll}
\hline \multirow{2}{*}{ Theme } & \multicolumn{8}{c}{ Theme } \\
\cline { 2 - 9 } & Rf & Ge & Gm & St & Lu & Sp & Ld & Dd \\
\cline { 2 - 9 } Rainfall (Rf) & 1.00 & 2.00 & 3.00 & 4.00 & 3.00 & 5.00 & 6.00 & 8.00 \\
Geology (Ge) & 0.50 & 1.00 & 2.00 & 3.00 & 2.00 & 5.00 & 6.00 & 7.00 \\
Geomorphology (Gm) & 0.33 & 0.50 & 1.00 & 2.00 & 2.00 & 5.00 & 6.00 & 7.00 \\
Soil type (St) & 0.25 & 0.33 & 0.50 & 1.00 & 2.00 & 3.00 & 7.00 & 8.00 \\
LULC (Lu) & 0.33 & 0.50 & 0.50 & 0.50 & 1.00 & 7.00 & 5.00 & 8.00 \\
Slope (Sp) & 0.20 & 0.20 & 0.20 & 0.33 & 0.14 & 1.00 & 0.33 & 4.00 \\
Lineament Density (Ld) & 0.17 & 0.17 & 0.17 & 0.14 & 0.20 & 3.00 & 1.00 & 2.00 \\
Drainage Density (Dd) & 0.13 & 0.14 & 0.14 & 0.13 & 0.13 & 0.25 & 0.50 & 1.00 \\
\hline
\end{tabular}

The relative weight matrix and normalized weights were determined based on the PCM to determine the percentage of impact on groundwater recharging of the thematic layers (Table 3). 
Table 3: Determining the normalized weights for thematic layers

\begin{tabular}{|c|c|c|c|c|c|c|c|c|c|c|}
\hline \multirow{2}{*}{ Theme } & \multicolumn{8}{|c|}{ Theme } & \multirow{2}{*}{ 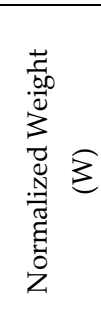 } & \multirow{2}{*}{ 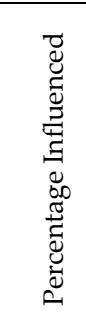 } \\
\hline & Rf & $\mathrm{Ge}$ & $\mathrm{Gm}$ & St & $\mathrm{Lu}$ & Sp & $\mathrm{Ld}$ & $\mathrm{Dd}$ & & \\
\hline Rainfall (Rf) & 0.34 & 0.41 & 0.40 & 0.36 & 0.29 & 0.17 & 0.19 & 0.18 & 0.29 & 29 \\
\hline Geology (Ge) & 0.17 & 0.21 & 0.27 & 0.27 & 0.19 & 0.17 & 0.19 & 0.16 & 0.20 & 20 \\
\hline $\begin{array}{l}\text { Geomorphology } \\
(\mathrm{Gm})\end{array}$ & 0.11 & 0.10 & 0.13 & 0.18 & 0.19 & 0.17 & 0.19 & 0.16 & 0.15 & 15 \\
\hline Soil type (St) & 0.09 & 0.07 & 0.07 & 0.09 & 0.19 & 0.10 & 0.22 & 0.18 & 0.13 & 13 \\
\hline LULC (Lu) & 0.11 & 0.10 & 0.07 & 0.05 & 0.10 & 0.24 & 0.16 & 0.18 & 0.12 & 12 \\
\hline Slope (Sp) & 0.07 & 0.04 & 0.03 & 0.03 & 0.01 & 0.03 & 0.01 & 0.09 & 0.04 & 4 \\
\hline $\begin{array}{l}\text { Lineament } \\
\text { Density (Ld) }\end{array}$ & 0.06 & 0.03 & 0.02 & 0.01 & 0.02 & 0.10 & 0.03 & 0.04 & 0.04 & 4 \\
\hline $\begin{array}{l}\text { Drainage } \\
\text { Density (Dd) }\end{array}$ & 0.04 & 0.03 & 0.02 & 0.01 & 0.01 & 0.01 & 0.02 & 0.02 & 0.02 & 2 \\
\hline & & & & & \multicolumn{6}{|c|}{$\begin{array}{r}\mathrm{CI}=0.123, \mathrm{n}=8, \mathrm{RI}=1.4, \lambda \max =8.86 \\
\text { Consistency Ratio }(\mathrm{CR})=0.088<0.1\end{array}$} \\
\hline
\end{tabular}

The key principle for checking the comparison order is that the consistency ratio(CR) not equal to 0.1 indicates a satisfactory reciprocal matrix. The ratio above 0.1 indicates the change of the PCM [26]. The CR is determined using the following equation:

$$
\mathrm{CR}=\frac{\mathrm{CI}}{\mathrm{RI}^{\prime}}
$$

where RI is the random index, the value of RI for different $\mathrm{n}$ values depends on the order of the matrix, and CI is the consistency index which can be expressed as follows:

$$
\mathrm{CI}=\frac{\lambda \max -\mathrm{n}}{\mathrm{n}-1},
$$

Here, $(\lambda \max )$ is a principal eigenvalue, $\mathrm{n}$ is the number of factors, and $\mathrm{CI}$ is the consistency index. The CR value for consistent weights should be below 0.10 ; in the absence of this, corresponding weights should be re-examined to prevent inconsistency [28]. In this study, the $C R$ is found $0.088(\lambda \max =8.86, n=8, R I=1.41, C I=0.123)$; which indicates a good consistency in the pairwise matrix comparison (Table 3). Hence, the AHP technique exhibits reasonable precise spatial prediction of groundwater probability.

\subsubsection{Normalized weights of different features of thematic layers}

The attributes of each of the thematic maps were assigned a weightage of 1-5 (1 denotes very low, 2 implies low, 3 indicate moderate, 4 represents high, and 5 denotes very high), considering its influence on the occurrence of groundwater $[9,12,27,30-32]$. Table 4 displays the ranks of different features of the individual themes and their normalized weights regarding groundwater potentiality. Every thematic layer has five classes, and their interdependence is too complicated. Therefore, the relationship between different features of the individual themes is achieved using other ranks and distinguished by using AHP. 
Table 4: Assigned and normalized weights of different features of thematic layers for potential groundwater zoning

\begin{tabular}{|c|c|c|c|c|}
\hline 旁 & Feature/ classes & 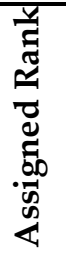 & 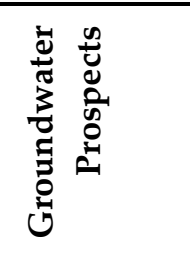 & 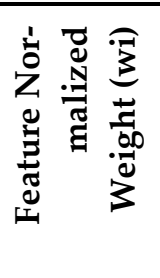 \\
\hline \multirow{6}{*}{ 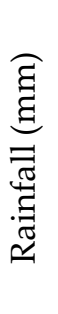 } & $<97$ & 1 & Very Low & 0.067 \\
\hline & $97-100$ & 2 & Low & 0.133 \\
\hline & $100-103$ & 3 & Moderate & 0.2 \\
\hline & 103-106 & 4 & High & 0.267 \\
\hline & $>106$ & 5 & Very High & 0.333 \\
\hline & Total & 15 & & \\
\hline
\end{tabular}

Alluvial and lagoonal clay, silt

sand

Beach and dune sand

के Jaffna limestone, Minihagalkanda Beds

Red earth, red and brown sand

Undifferentiated Vijayan gneiss with trend lines

Total 15

Beach ridges, bars and spits

Low plantation surface with inselbergs \& thin soil (dry zone) 3

Moderate

0.2

4

High

0.267

$5 \quad$ Very High

0.333

2

Low

0.133

$1 \quad$ Very Low

0.067

के
0
0
0
0
0
0
0
0
0

River plains and adjacent coastal lowlands

Upwarped pleistocence coastal

plain
Plateau of Miocene limestones

3

Moderate

0.200

4

High

0.267

2

Low

0.133

$1 \quad$ Very Low

0.067

Plateau of Miocene limestones

5

Very High

0.333

Total 15

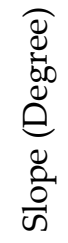

$\begin{array}{rl}<0.5 & 5\end{array}$

Very High

0.333

$0.5-1 \quad 4$

High

0.267

1- $1.5 \quad 3$

Moderate

0.2

1.5 - $2 \quad 2$

Low

0.133

$>2 \quad 1$

Very Low

0.067

Total 15

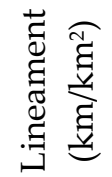

$<0.08$
$0.08-0.23$
$0.23-0.41$
$0.41-0.62$
$>0.62$

Very Low

0.067

Low

0.133

Moderate

High

0.267

Very High 


\begin{tabular}{|c|c|c|c|c|}
\hline & Total & 15 & & \\
\hline \multirow{6}{*}{ 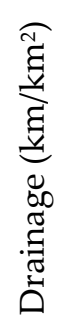 } & $<28.47$ & 5 & Very High & 0.333 \\
\hline & $28.47-56.94$ & 4 & High & 0.267 \\
\hline & $56.94-85.42$ & 3 & Moderate & 0.200 \\
\hline & $85.42-113.89$ & 2 & Low & 0.133 \\
\hline & $>113.89$ & 1 & Very Low & 0.067 \\
\hline & Total & 15 & & \\
\hline \multirow{6}{*}{ 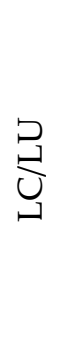 } & Forest & 4 & High & 0.267 \\
\hline & Agriculture\& Fallow Land & 3 & Moderate & 0.200 \\
\hline & Bare Land & 2 & Low & 0.133 \\
\hline & Settlements & 1 & Very Low & 0.067 \\
\hline & Water bodies & 5 & Very High & 0.333 \\
\hline & Total & 15 & & \\
\hline \multirow{6}{*}{$\begin{array}{l}\overline{\bar{D}} \\
\text { ஸे }\end{array}$} & $\begin{array}{r}\text { Alkali and saline soils of variable } \\
\text { texture (Solodized solonets and } \\
\text { solonchaks) }\end{array}$ & 4 & High & 0.308 \\
\hline & Alluvial soils of variable texture & 3 & Moderate & 0.231 \\
\hline & Red-Yellow Podzolic soils & 2 & Low & 0.154 \\
\hline & Red-Yellow latosols & 1 & Very Low & 0.077 \\
\hline & $\begin{array}{r}\text { Sand regosols on recent beach } \\
\text { and dune sands }\end{array}$ & 5 & Very High & 0.231 \\
\hline & Total & 15 & & \\
\hline
\end{tabular}

\subsubsection{Groundwater Potential Index}

The groundwater potential index (GWPI) is a dimensionless quantity that helps predict the potential groundwater zones in an area $[6,9,12,15,26]$. The weighted linear combination method was used to estimate the GWPI. The following equation was applied to integrate all the themes for obtaining the potential groundwater zone as stated bellow

$$
\begin{aligned}
G W P I=\left(G m_{w} G_{w i}\right)+ & \left(G_{w} G_{w i}\right)+\left(L_{w L c} L u L c_{w i}\right)+\left(D_{w} D d_{w i}\right)+\left(S p_{w} S p_{w i}\right)+ \\
& \left(L_{w} L d_{w i}\right)+\left(S t_{w} S t_{w i}\right)+\left(R_{w} R_{w i}\right),
\end{aligned}
$$

Where Ge stands for geology, Gm stands for geomorphology, LuLc stands for land use/land cover, Dd stands for drainage density, Sp stands for the slope, Ld stands for lineament density, St stands for soil type, Rf stands for rainfall, $\mathrm{w}$ stands for the normalized weight of a theme, and wi stands for the normalized weight of each class. 


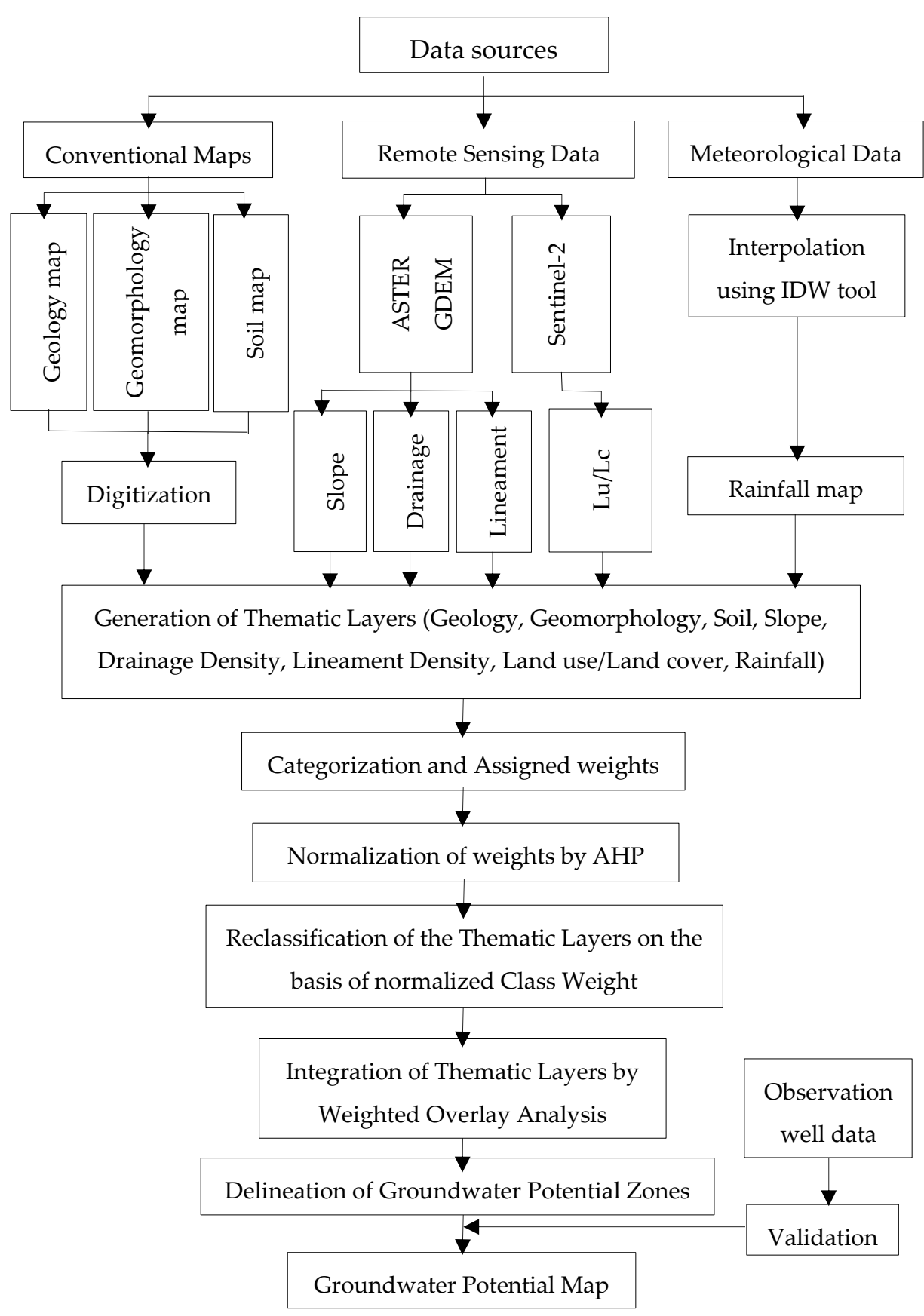

Figure 2: Flowchart of the methodology used for delineating potential groundwater zones

\section{Results}

\subsection{Factors affecting the groundwater potentiality in the study area}

\subsubsection{Geology}

Geology determines the aquifers which store groundwater. The porosity and permeability of a formation assess its quality as an aquifer [16,33]. The spatial distribution of groundwater is primarily influenced by the geological characteristics of an area $[1,26,33-$ 35]. The geology map of the Kilinochchi district was prepared by digitizing the geology map of Sri Lanka, published by the Geological Survey and Mines Bureau of Sri Lanka. Five types of geology, namely Alluvial and lagoonal clay silt sand and Red earth, red \& brown sand, Beach \& dune sand, Miocene limestone (Jaffna limestone), and Undifferentiated Vijayan gneiss with trend lines, are found in the study area. The detailed geological map of the study area is presented in Fig.3. In general, this area belongs to Phanerozoic 
rock and Precambrian rock. The Phanerozoic rock comprises Alluvial \& lagoonal clay silt sand, Red earth red \& brown sand, Beach \& dune sand, Miocene limestone (Jaffna limestone). Precambrian rock consists of Undifferentiated Vijayan gneiss with trend lines. Alluvial and lagoonal clay silt sand distributed most of the study area predominantly.

The western part mainly comprises Red earth, red \& brown sand. Alluvial and lagoonal clay silt sand mostly is found in the eastern part of the district. Beach \& dune sand was found in the study area as patches. Miocene limestone (Jaffna limestone) found in the northern part has high groundwater potential. The zones having less compaction, a high degree of weathering, and a high degree of infiltration of runoff are more suitable for groundwater recharging [21]. Sedimentary rocks have higher primary porosity and permeability than other types of rocks [16]. Hence, the various rock units in the study area are assigned appropriate weights based on their textural properties and the potential for fractured zone formation. Based on the nature of increasing groundwater potentiality, the high weight was assigned to Miocene limestone (Jaffna limestone), whereas low weight was assigned to Undifferentiated Vijayan gneiss (Table 4). The groundwater potential map validated with field observation reveals that Miocene limestone (Jaffna limestone) has the highest groundwater potential.

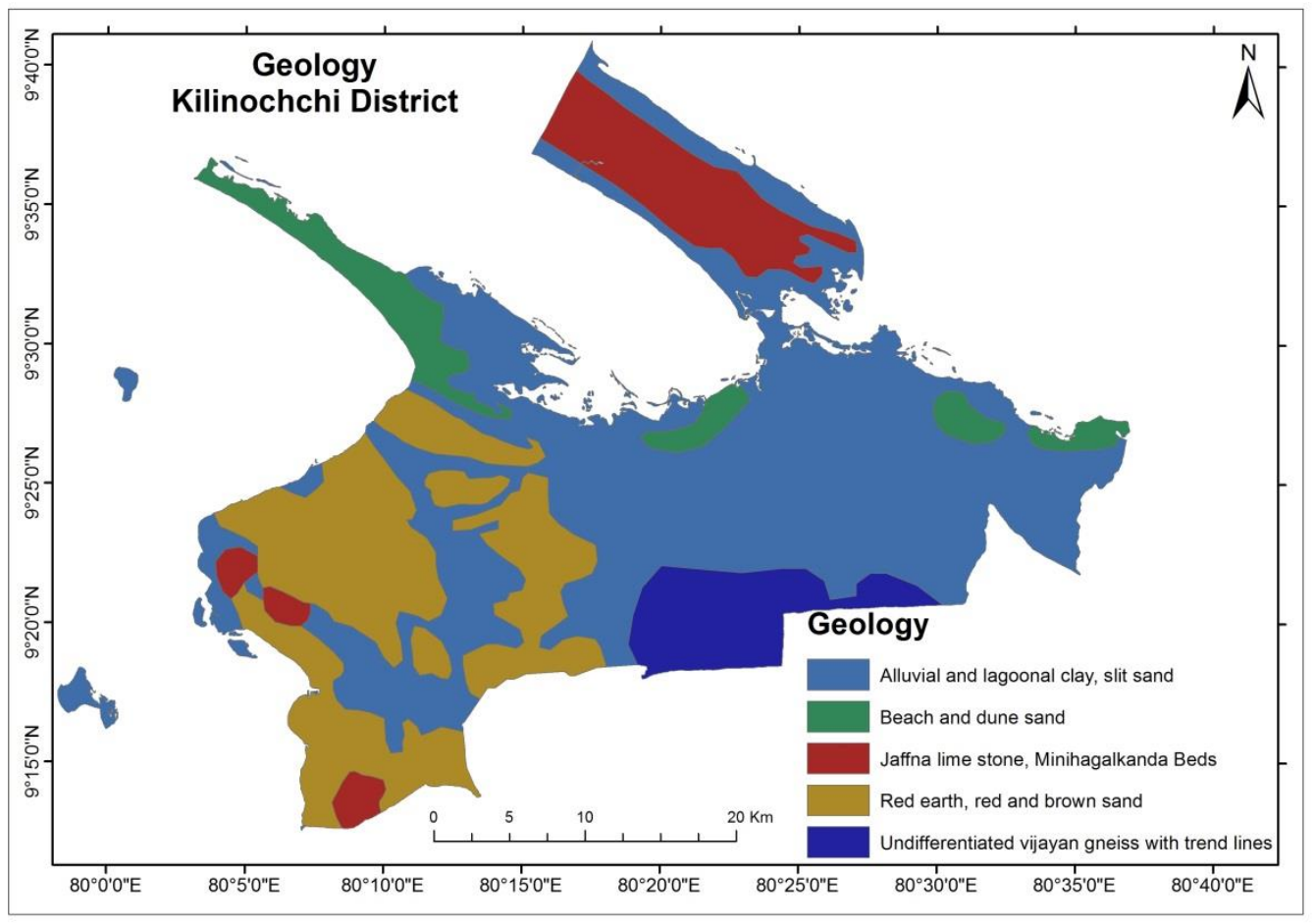

Figure 3: Geology map of Kilinochchi District

\subsubsection{Geomorphology}

Geomorphology is a study of landforms that includes their description, species, and physical processes that have helped evaluate possible ground water areas [26,33]. Geomorphological components are significant in hydro-geological investigations and the identification of groundwater resources $[9,33,34]$. Morphology has a positive influence on the percolation of water into the subsurface of the Earth [12,13,36]. Geomorphology is considered an essential component for groundwater recharge as the evolution of landforms explains porous and permeable zones [21]. The geomorphology map of the Kilinochchi district was prepared by digitizing the geomorphology map of Sri Lanka, published by the Geological Survey and Mines Bureau of Sri Lanka. The lithology and geological formation of the study area are highly influenced by geomorphology. The primary geomorphological units of the study area are divided into five types: Beach ridges, bars \& spits, Low plantation surface with inselbergs \& thin soil, River plains \& adjacent coastal lowlands, 
Upwarped Pleistocene coastal plain, and plateau of Miocene limestones. The major portion is occupied by River plains \& adjacent coastal lowlands in the district, while the western part is predominantly formed Upwarped Pleistocene coastal plain (Fig. 4). Geomorphological features are weighted in terms of their importance over groundwater occurrence (Table 4). Among these morphological features, the plateau of Miocene limestones has been assigned high weight as it has good potential for groundwater. Still, Upwarped Pleistocene coastal plain landforms are assigned low weight as they are unsuitable for potential groundwater zones.

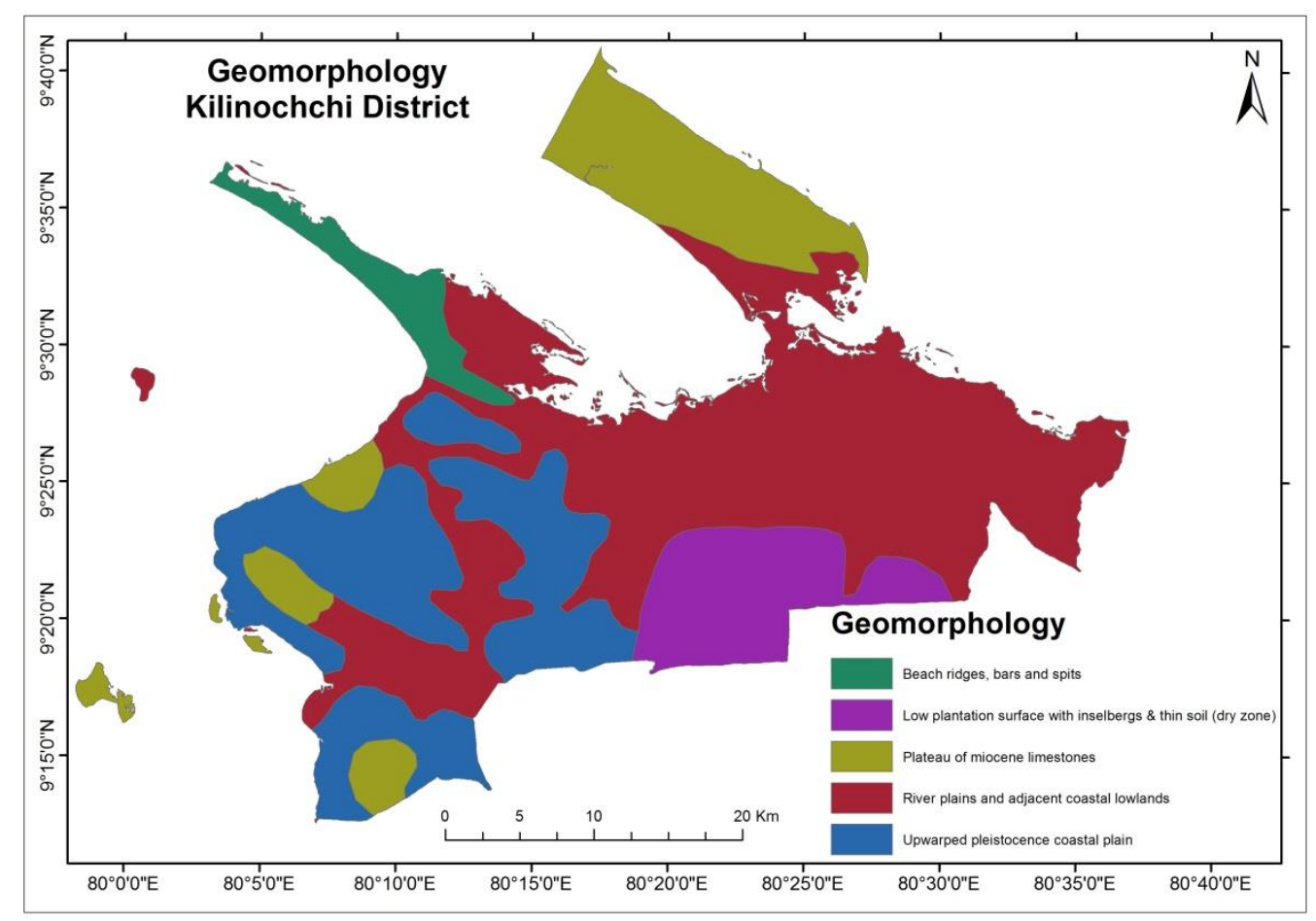

Figure 4: Geomorphology map of Kilinochchi District

\subsubsection{Slope}

The slope (the rate of elevation change) is also a key factor in identifying potential groundwater zones [3]. It can be used as an indicator for demarcating potential groundwater zones as it directly controls the groundwater recharge rate [9]. Generally, an inverse relationship can be seen between the slope and the infiltration rate. Surface water penetration is regulated directly by the slope gradient $[1,3,9,13,23]$. Steep slope experiences a low penetration level due to the rapid flow of water downwards and insufficient time for infiltration, whereas the flat surface facilitates groundwater recharge by retaining rainwater $[1,9,37]$. The slope map of the Kilinochchi district was derived from the ASTER-GDEM. The slope gradient of the district ranges from $<0.50$ to $>2.00$. The slope of the entire district has been categorized into five classes, viz, $<0.50,0.50-10,10-1.50,1.50-20$, and $>20$. Weights were assigned based on the slope categories given in Fig. 5. High weight was allocated for lower slopes due to the higher groundwater recharge rate and vice versa (Table 4). 


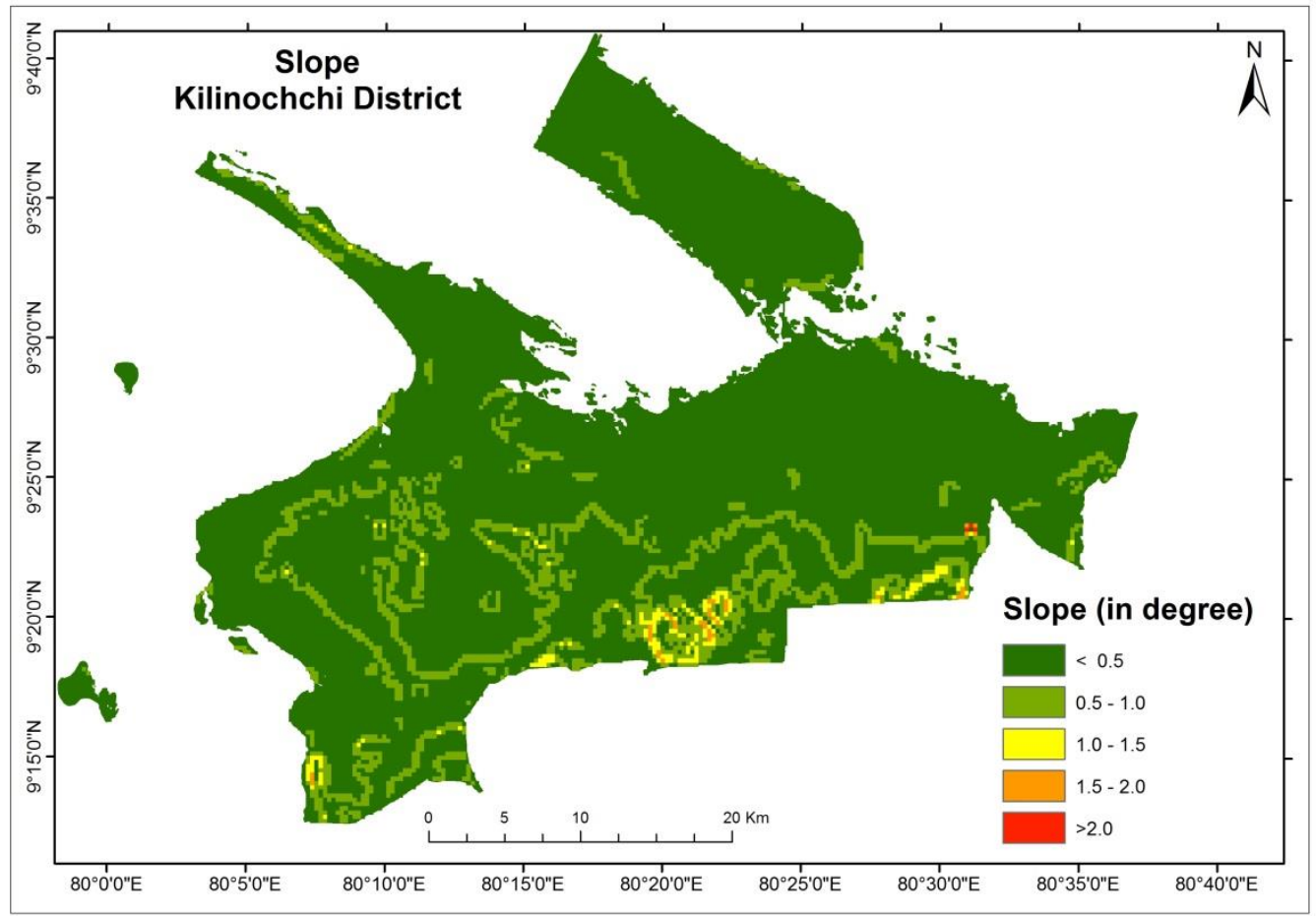

Figure 5: Slope map of Kilinochchi District

\subsubsection{Soil}

Surface water penetration into the aquifers is controlled by the soil [13]. In the unsaturated zone, moisture content, infiltration rate, grain size, and soil composition influence the groundwater movement $[9,33,38]$. Soil texture affects infiltration rate since the texture varies with porosity and permeability $[1,33]$. The soil map of the Kilinochchi district was prepared by digitizing the soil map of Sri Lanka, published by the Geological Survey and Mines Bureau of Sri Lanka. Five soil types are described in the study area: Alkali \& saline soils of variable texture (Solodized solonets and solonchaks), Alluvial soils of variable texture, and Red-Yellow Podzolic soils, Red-Yellow Latosols, and Sand Regosols on the recent beach and dune sands (Figure. 6). The soil type analysis shows that the study area primarily covered by Red-Yellow Latosols followed by Alkali \& saline soils of variable texture (Solodized solonetz and solonchaks) was observed along the northern and western margin of the coast. Alluvial soils of variable texture mainly cover the middle and eastern parts. Sand Regosols on the recent beach and dune sands also occur in the northern boundary of the area. Red-Yellow Podzolic soil covers the smaller portion in the southern part of the study area (Figure. 6). The weights of soils are assigned according to their degree of infiltration [26,39]. Sand Regosols on the recent beach and dune sands soil have a high infiltration rate and, therefore, higher priority. In contrast, the Red-Yellow Latosols soil has the lowest infiltration rate and, therefore, is given as low priority (Table $4)$. 


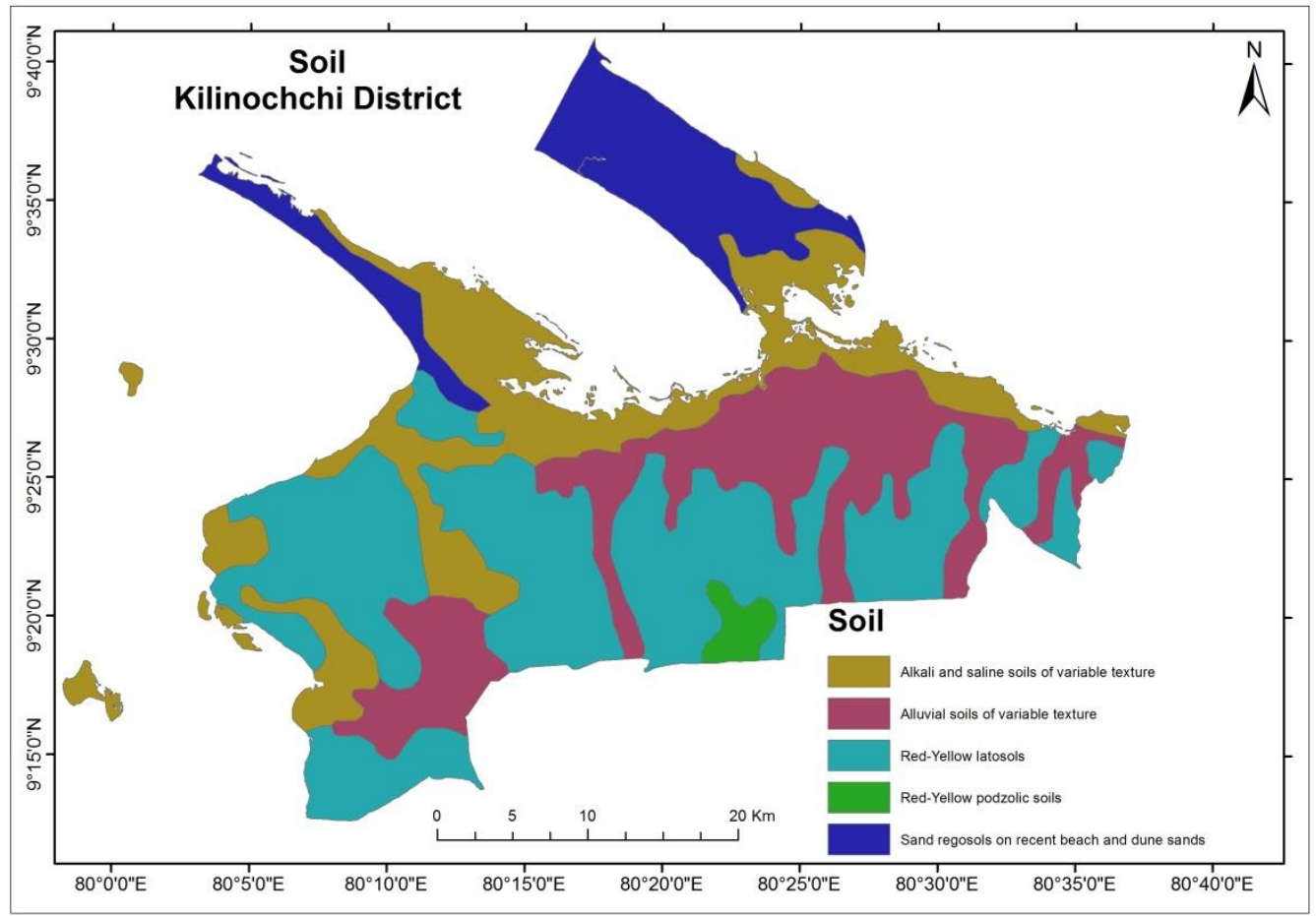

Figure 6: Soil map of Kilinochchi District

\subsubsection{Drainage density}

Drainage density is one of the influential factors in groundwater potential that control surface runoff and permeability [26,33]. Drainage density and the drainage structure are generally controlled by geology, slopes, and structures [26,33]. Drainage density is the proximity of the distance between stream channels, and it indicates the ratio between the total stream length and total area $[3,15,35,40]$. The drainage density of the Kilinochchi district was prepared from the ASTER GDEM in ArcGIS 10.4. platform. Figure.7 shows the drainage density of the study area. The less permeable layer below the high drainage density area increases surface runoff, indicating less groundwater potential. Therefore, the region with a high drainage density is unlikely to suit groundwater [12]. The drainage density varies between $<28.48$ and $113.89 \mathrm{~km} / \mathrm{km}^{2}$ in the study area and are categorized into five categories namely $<28.47 \mathrm{~km} / \mathrm{km}^{2}, 28.47-56.94 \mathrm{~km} / \mathrm{km}^{2}, 56.94-85.42 \mathrm{~km} / \mathrm{km}^{2}$, $85.42-113.89 \mathrm{~km} / \mathrm{km}^{2},>113.89 \mathrm{~km} / \mathrm{km}^{2}$. High weights have been allocated to the lowdrainage area for potential groundwater delineation, while high drainage area has been assigned low weights. 


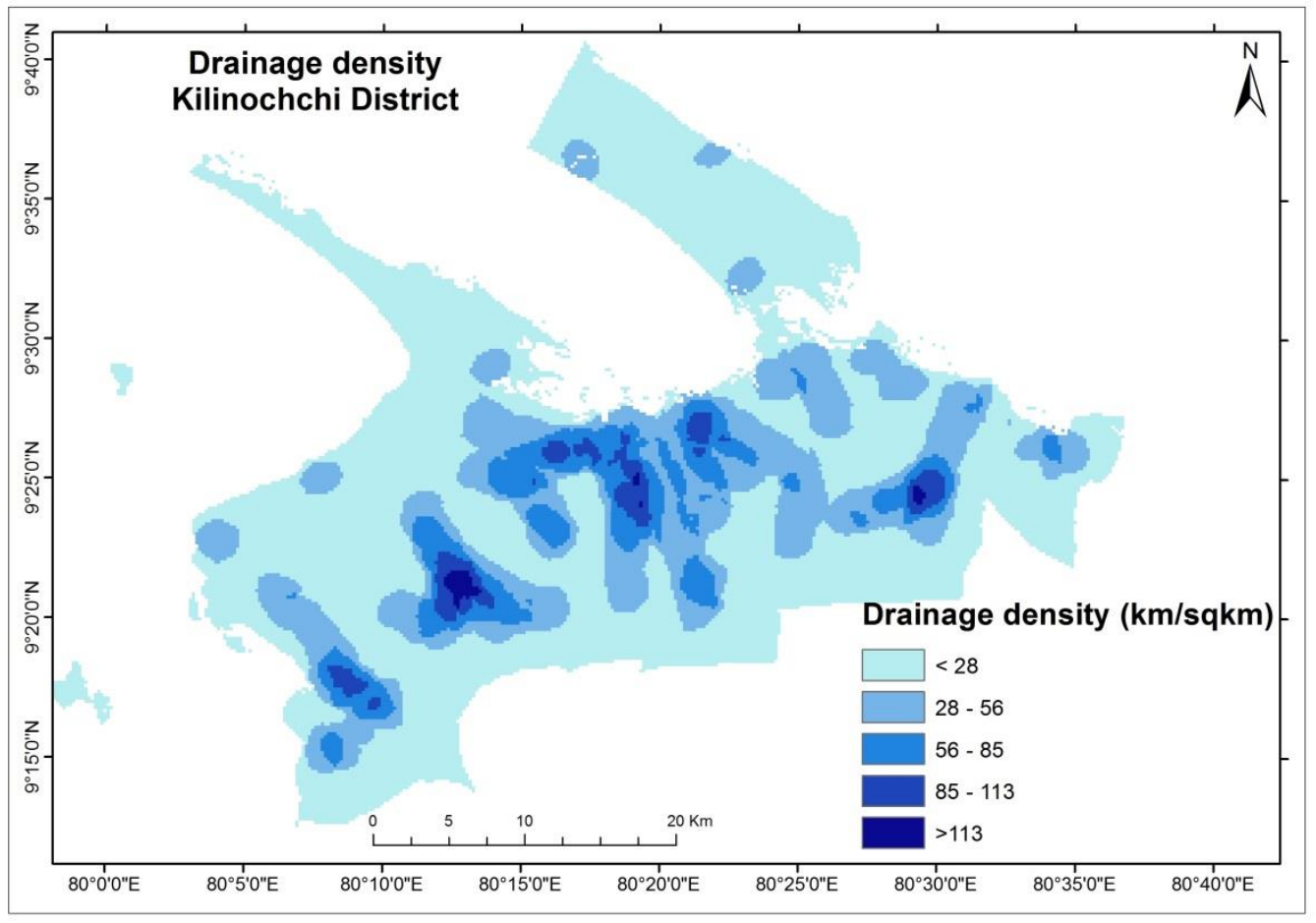

Figure 7: Drainage density map of Kilinochchi District

\subsubsection{Lineament density}

Linear and curvilinear structural features of an area support groundwater movement and infiltration $[2,9,12,23,41]$. Higher lineament densities are considered ideal for the development of groundwater [31]. The lineament map of the study area was generated from ASTER GDEM. The lineament density of the study area varies from $<0.08$ to $>0.62 \mathrm{~km} / \mathrm{km}^{2}$ (Figure 08). The lineament density, shown in Figure. 8, is natural, linear or curvilinear features, and was classified into five classes namely, $<0.08 \mathrm{~km} / \mathrm{km}^{2}, 0.08-0.23 \mathrm{~km} / \mathrm{km}^{2}$, $0.23-0.41 \mathrm{~km} / \mathrm{km}^{2}, 0.41-0.62 \mathrm{~km} / \mathrm{km}^{2},>0.62 \mathrm{~km} / \mathrm{km}^{2}$. The weights were assigned based on density. Low lineament density was assigned low weight, whereas high weight was assigned to high lineament density (Table 4). 


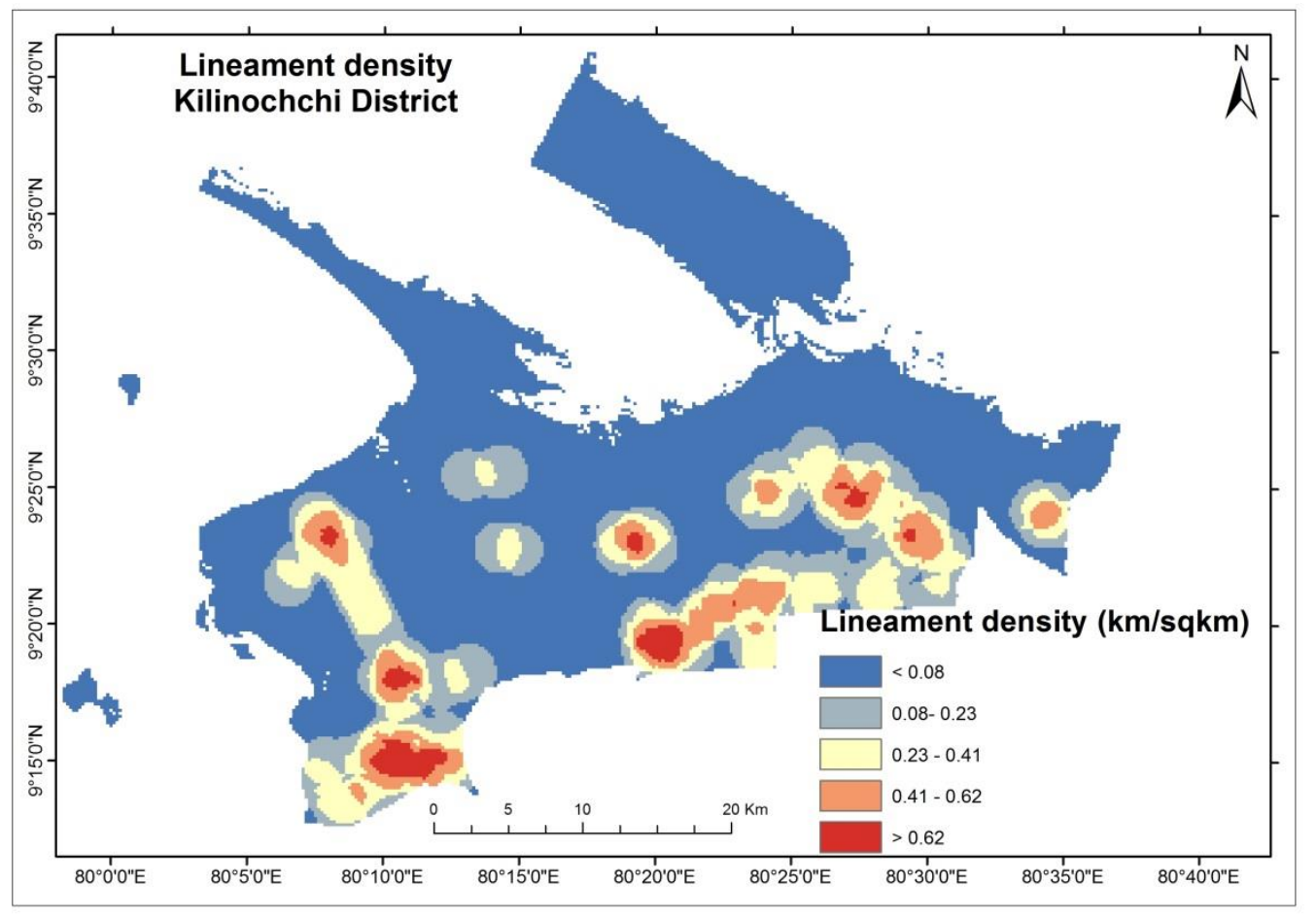

Figure 8: Lineament density map of Kilinochchi District

\subsubsection{Rainfall}

Rainfall impacts significantly the hydrological cycle, which has a dominant effect on the area's groundwater capacity $[3,30,40]$. The amount of infiltration heavily depends on the intensity and duration of rainfall [3,35]. About $75 \%$ of the district's total rainfall is from North-East Monsoon from September to December [22]. There are only a few rain gauge stations in the Kilinochchi district. Annual rainfall data was obtained from three stations: Iranamadu, Akkarayan, and Kariyalainagapaduvan. The rainfall data were spatially interpolated with IDW to obtain the rainfall distribution map. The yearly precipitation of the study area varies between 94 and $107 \mathrm{~mm} \mathrm{[22]} \mathrm{and} \mathrm{is} \mathrm{classified} \mathrm{into} \mathrm{five} \mathrm{categories} \mathrm{as}$ $<97 \mathrm{~mm}, 97-100 \mathrm{~mm}, 100-103 \mathrm{~mm}, 103-106 \mathrm{~mm},>106 \mathrm{~mm}$ (Figure.9). The weights were assigned based on the intensity and its potential to groundwater. The high intensity of rainfall was assigned high weight, whereas low weight was allocated to the low intensity (Table 4). The thematic rainfall map of the Kilinochchi district indicates that although there is high rainfall in the eastern region, the western part of the district has relatively low rainfall (Figure.9). 


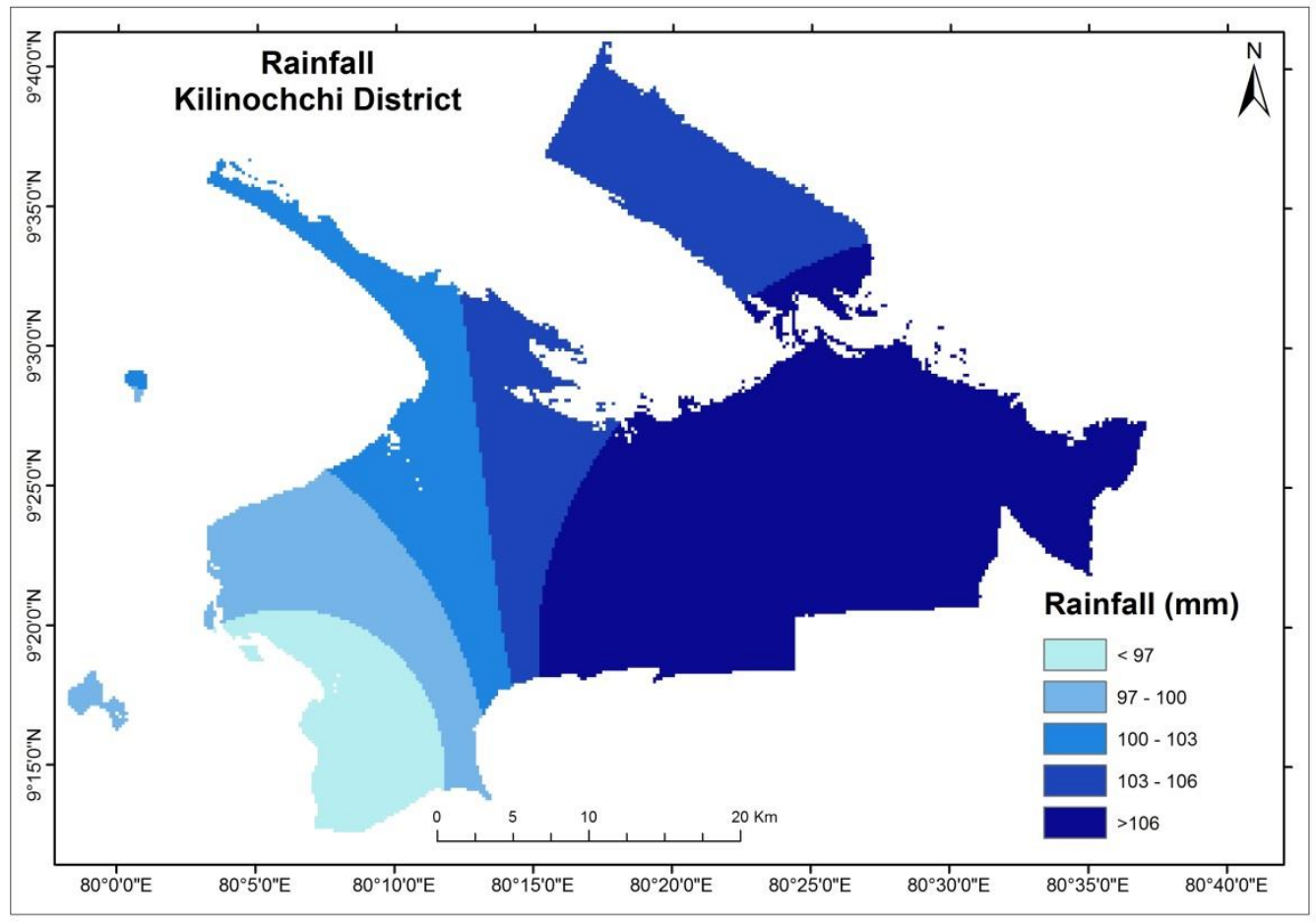

Figure 9: Rainfall distribution map of Kilinochchi District

\subsubsection{Land use/Landcover}

Groundwater recharge depends on the area's LULC [2,9]. It provides essential information on infiltration, soil moisture, groundwater, surface water, etc. [33,42]. The land use and change map was generated from the Sentinel-2 imagery of may 2020, acquired from USGS Earth Explorer and classified using supervised classification ArcGIS 10.4. Forests, agriculture \& fallow lands, barren land, settlements, and water bodies are the main categories of land used found in the area (Figure.10). The land used for water bodies and vegetation is highly suitable for groundwater recharge [33]. Water bodies retain surface water during the monsoon period, and forest cover increases infiltration by minimizing runoff. The land used for agricultural purposes can be categorized as moderately suitable land for groundwater recharge. The built-up area is categorized as the least suitable area for groundwater recharge [1]. The weights were given according to their potential for groundwater recharge. The water bodies are allocated the high weight, and the settlements are allocated the least weight (Table 4). 


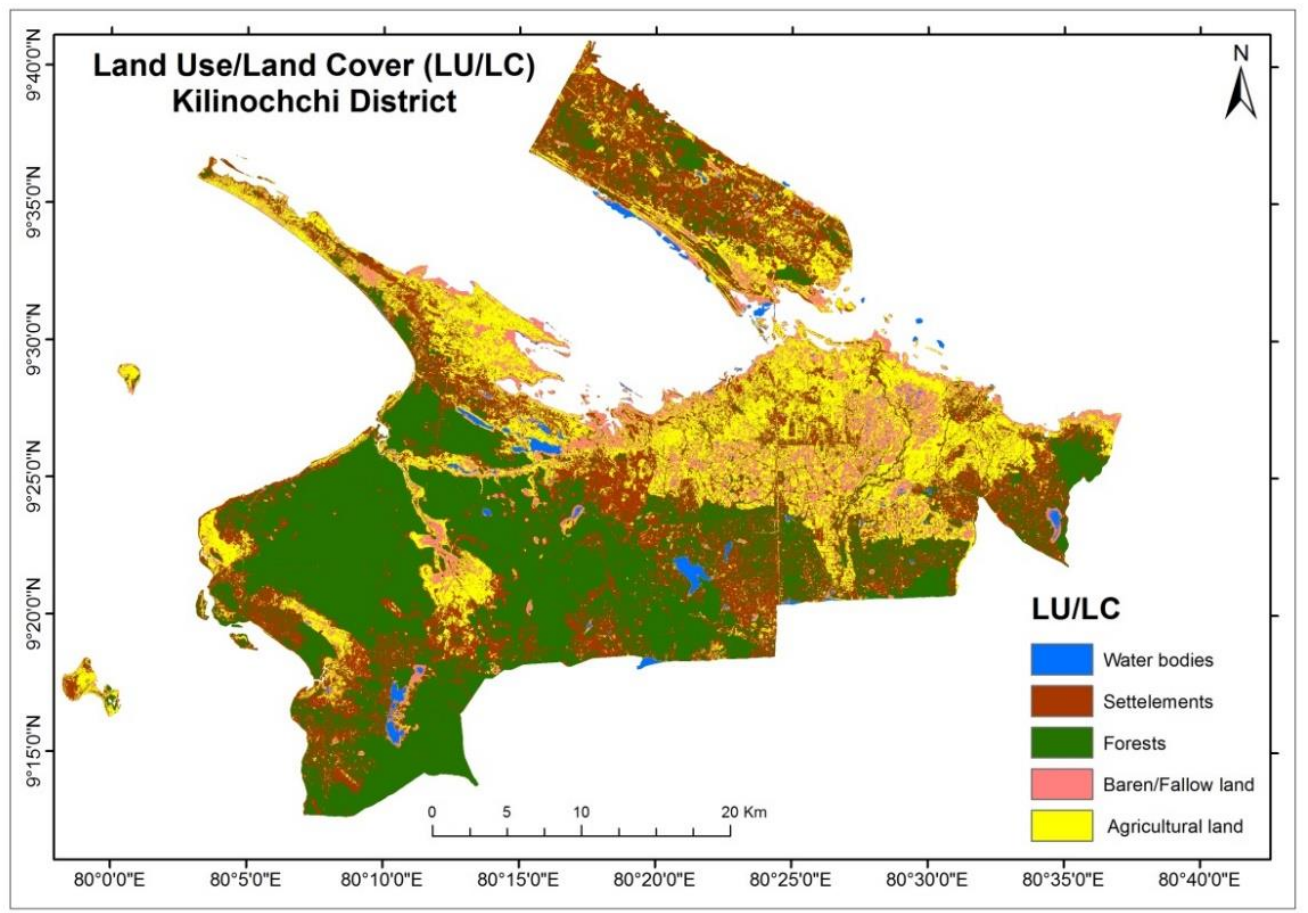

Figure 10: Land use /Land cover map of Kilinochchi District

\section{Results}

\subsection{Delineation of potential groundwater zone}

Geomorphology, geology, soil, and rainfall play an essential role in the study area's groundwater potential. The integrated RS, GIS, and AHP technical methods have been applied to delineate potential groundwater zones. In PCM, the expert's opinions and field knowledge were used to assign importance to each theme on Saaty's scale. Geology obtained the highest normalized weight, followed by rainfall, geomorphology, land use land cover, lineament density, soil, slope, and drainage density.

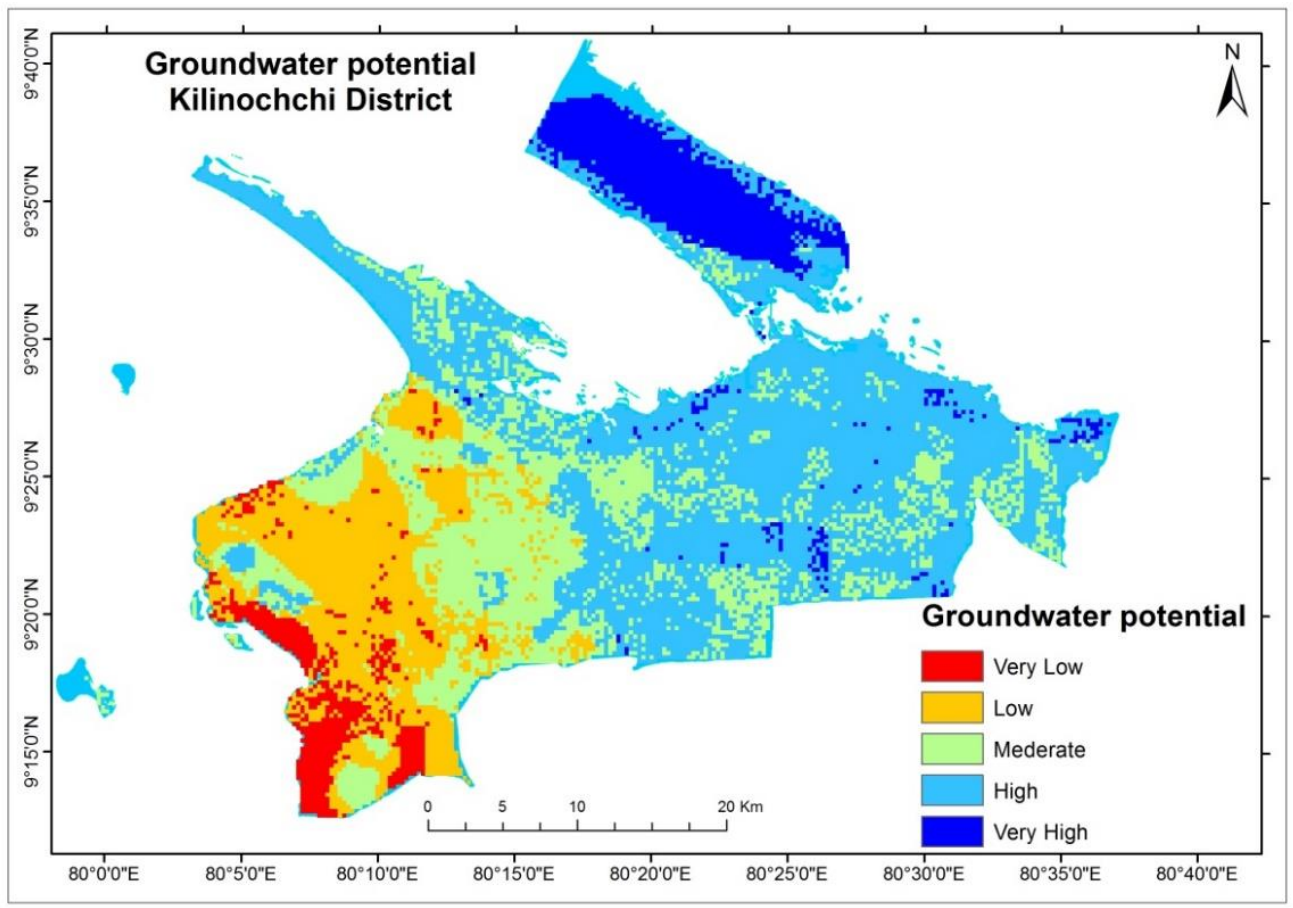

Figure 11: Groundwater Potential Zone map of Kilinochchi District 
The groundwater potential map are classified into five classes namely very high $\left(111.26 \mathrm{~km}^{2}\right)$, high $\left(507.74 \mathrm{~km}^{2}\right)$, moderate $\left(309.89 \mathrm{~km}^{2}\right)$, low $\left(207.78 \mathrm{~km}^{2}\right)$ and very low $\left(59.12 \mathrm{~km}^{2}\right)$ covering about $9 \%, 42 \%, 26 \%, 17 \%$ and $5 \%$ respectively (Table 5$)$. The normalized weights of the eight thematic layers indicate that geology and rainfall influence more than other factors in the occurrence of the potential groundwater zones (Table 3 ).

Table 5: Groundwater potential region

\begin{tabular}{ccc}
\hline Categories & Area $\mathrm{Km}^{2}$ & Area $(\%)$ \\
\hline Very Low & 59.12 & 5 \\
Low & 207.78 & 17 \\
Moderate & 309.89 & 26 \\
High & 507.74 & 42 \\
Very High & 111.26 & 9 \\
\hline
\end{tabular}

The map shown in Figure. 11 gives an overview of groundwater potential in the study area. Groundwater potentiality map of Kilinochchi district shows that the very high groundwater potential zone is predominantly found in the north-eastern part, which includes several Grama Niladhari (GN) divisions under Pachchilaipalli Divisional Secretariat (DS) (e.g., Masar, Soranpattu, Mullaiyadi, Pulopalai, Palai town, Tharmakerny, Kachcharvely, Vembatukerny, Kilali) due to high rainfall (103mm-106mm), Jaffna limestone, Sand Regosols on the recent beach \& dune sands, flat terrine, and Plateau of Miocene limestones. It indicates that rainfall, geology, geomorphology, and soil significantly contribute to groundwater augmentation in the Kilinochchi district. The upper north-western, middle \& eastern parts of the study area (Karachchi DS division, Kandawalai DS division and Northern part of Poonakary DS division) generally have high groundwater potential due to high annual average rainfall $(>106 \mathrm{~mm})$, flat terrain with less than 0.5 degree slope, Alluvial \& lagoonal clay, silt sand, and agricultural land. Moderate groundwater potentials zones exist mainly in the west part and small patches in the central and eastern parts of the study area (Poonakary DS division). As a result of less annual average rainfall (<94 mm), Red-Yellow Latosols soil, Upwarped Pleistocene coastal plain, Red earth, red and brown sand, lithology with less permeability, the western part of the study area (Poonakary DS division) is dominated by low and shallow groundwater potential areas. Furthermore, the groundwater potential map shows that, in addition to the significant control of geology and rainfall, the distribution of groundwater is influenced by land use/land cover, geomorphology, and soil. In addition, the area is underlain by Red earth, red and brown sand in the west part of the study area is characterized by relatively lower groundwater potential zones. However, this area comes under a moderate groundwater potential zone because of forests with a high infiltration rate.

\subsection{Validation of the groundwater potentiality}

Validation of the result is more important to have scientific significance [30,43]. Thus, during the pre-monsoon season between March 2020 and August 2020, 79 wells were selected using the stratified random sample to validate the findings in the study region (Figure. 12). The water depths of the wells observed ranged from $5.3 \mathrm{~m}$ to $19.2 \mathrm{~m}$. The observed wells were classified into five groups based on well water depth, including very high groundwater potential ( $<7 \mathrm{~m})$, high groundwater potential $(7-10 \mathrm{~m})$, moderate groundwater potential $(10-13 \mathrm{~m})$, low groundwater potential $(13-17 \mathrm{~m})$ and very low groundwater potential $(17 \mathrm{~m})$. To check the map's accuracy, the wells' water level was cross-checked against the prepared groundwater potential maps [1]. 


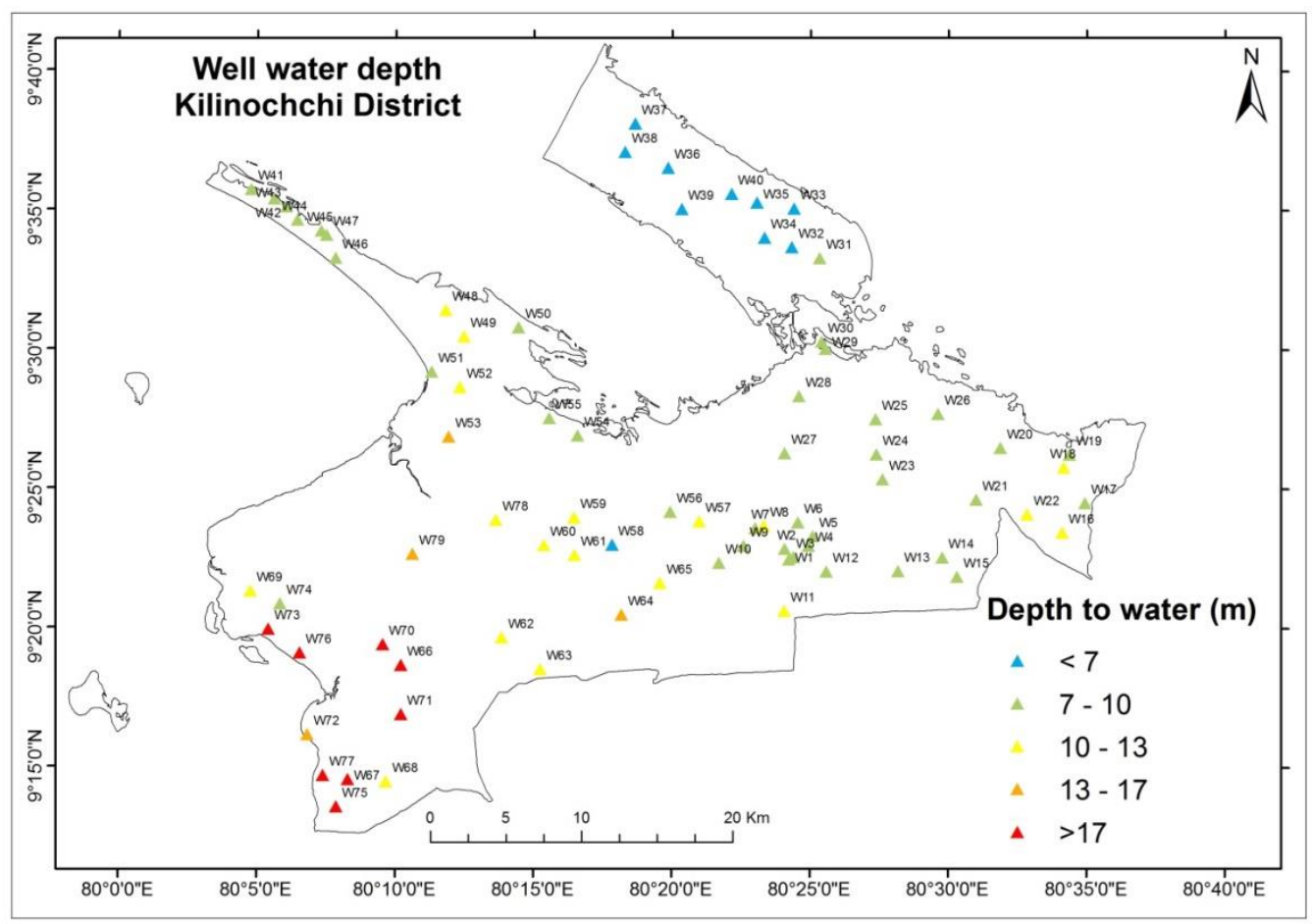

Figure 12: Validation Well map of Kilinochchi District

The Receiver Operating Characteristics (ROC) curve, which is a widely accepted technique for validating accuracy, was used to assess the accuracy of the model used $[1,14,26,30,44]$. The relation between Area Under Curve (AUC) and prediction accuracy can be summarized as Poor (0.5-0.6); average (0.6-0.7); good (0.7-0.8); very good (0.8-0.9); and excellent (0.9-1) [6,30]. The Kilinochchi district's groundwater potential map has been validated with 79 wells existing (Figure. 12). For varying cut-off points of a parameter, the true positive rate (sensitivity) is plotted to function the false-positive rate in a ROC curve. Each ROC curve point represents a pair of sensitivities, which corresponds to a certain decision threshold. According to the ROC graph, the area under the curve is measured and indicates an AUC value of 0.818 , referring to $81.8 \%$ of the prediction accuracy (Fig.13). Therefore, it can be implied that the methods used in this study exhibit an acceptable level of accuracy $(\mathrm{AUC}=81.8 \%)$ in delineating potential groundwater zones. 


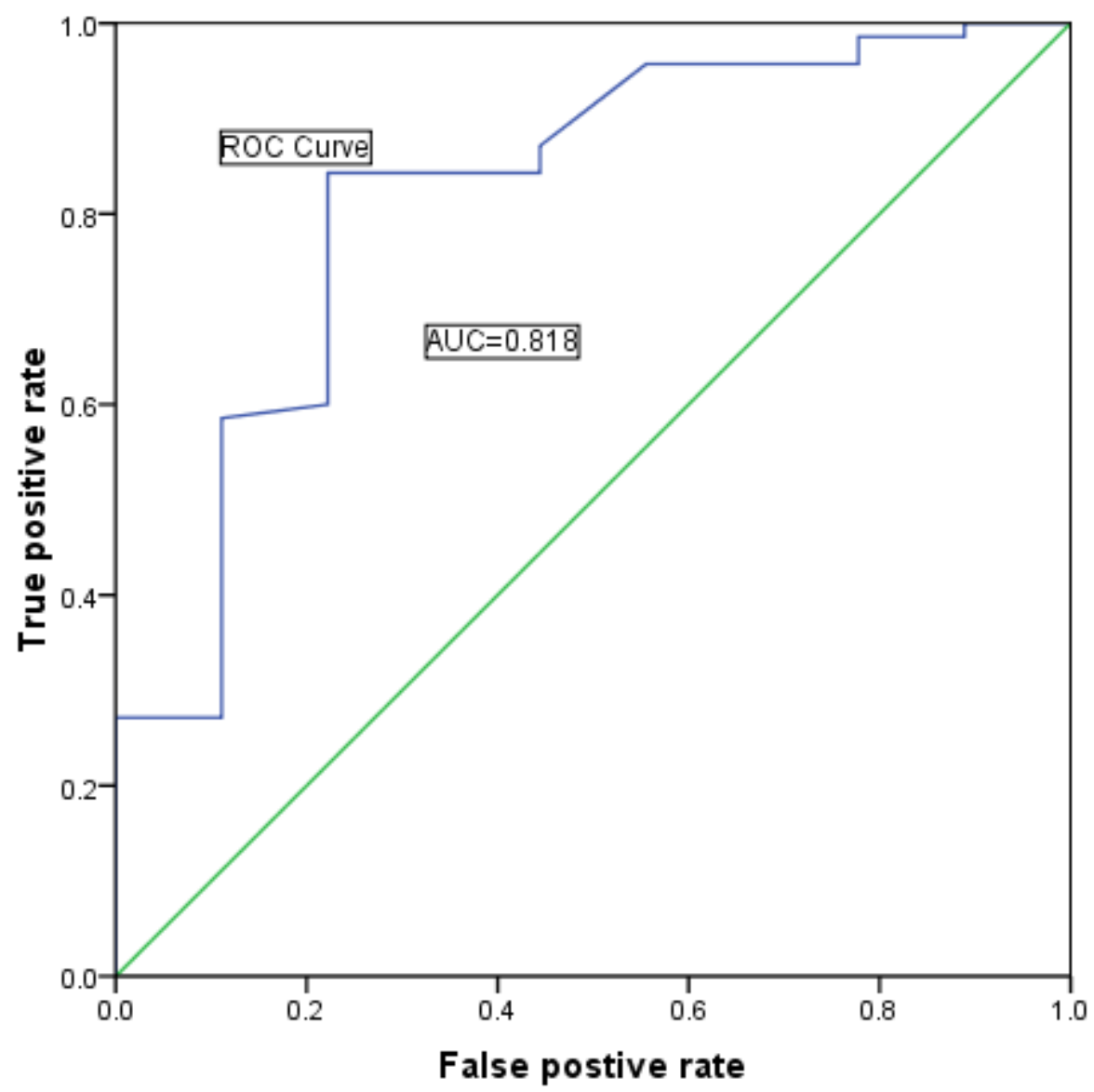

Figure 13: Receiver Operating Characteristics (ROC) curve

\section{Conclusion}

The integrated RS, GIS, and AHP techniques help identify the potential groundwater zone in a given area and provide reliable and cost-effective preliminary information about groundwater resources. An integrated platform of RS, GIS and AHP techniques was used to prepare the groundwater potential map of the Kilinochchi district. The AHP technique allocated thematic layers weights for the following categories: rainfall, geology, geomorphology, soil, drainage density, linear density, slope and land use cover. All thematic layers were integrated into ArcGIS 10.4.1 platform and generated a groundwater potential map. The resultant map has five categories, namely very high $\left(111.26 \mathrm{~km}^{2}\right)$, high $(507.74$ $\left.\mathrm{km}^{2}\right)$, moderate $\left(309.89 \mathrm{~km}^{2}\right)$, low $\left(207.78 \mathrm{~km}^{2}\right)$, and very low $\left(59.12 \mathrm{~km}^{2}\right)$. The very high potential zone is located in the north-eastern part of the study area (Pachchilaipalli DS division), which is highly favourable for groundwater prospecting. Very low potential zones are mainly found in the extreme western part of the Poonakary DS division, which is the least favourable for groundwater prospecting. About $48 \%$ of the Kilinochchi district falls into moderate to very low groundwater potential zones that should require special actions to increase groundwater conditions. The overall result indicates that the groundwater of the Kilinochchi district is influenced mainly by rainfall, geology, and soil factors. The ROC curve was eventually prepared to check the appropriateness of the approach used to delineate the potential groundwater zone. The validation result of GIS-based AHP indicates a reasonably good prediction accuracy of $81.8 \%$. It can be implied that the methods used to delineate potential groundwater zones in the Kilinochchi district are reliable. The methodology used in this study can be concluded as a useful framework for delineating the potential groundwater zones and can be recommended for use in others, partic- 
ularly in data scare areas. This research will help policymakers better manage the Kilinochchi district's groundwater resources and gives scope for further research into groundwater exploration in the area.

Author Contributions: The authors VP and NT proposed the topic and spearheaded the data processing and analysis, as well as the writing of the manuscript; MR helped to edit the manuscript.

Funding: This research received no external funding

Acknowledgements:

Conflicts of Interest: The authors declare no conflict of interest.

\section{Vyddiyaratnam Pathmanandakumar 1, Nadarajapillai Thasarathan ${ }^{2 *}$ and Manjula Ranagalage ${ }^{3,}$}

\section{References}

1. Das, B.; Pal, S.C. Combination of GIS and fuzzy-AHP for delineating groundwater recharge potential zones in the critical Goghat-II block of West Bengal, India. HydroResearch 2019, 2, 21-30, doi:10.1016/j.hydres.2019.10.001.

2. Das, B.; Pal, S.C.; Malik, S.; Chakrabortty, R. Modeling groundwater potential zones of Puruliya district, West Bengal, India using remote sensing and GIS techniques. Geol. Ecol. Landscapes 2019, 3, 223-237, doi:10.1080/24749508.2018.1555740.

3. Ibrahim-Bathis, K.; Ahmed, S.A. Geospatial technology for delineating groundwater potential zones in Doddahalla watershed of Chitradurga district, India. Egypt. J. Remote Sens. Sp. Sci. 2016, 19, 223-234, doi:10.1016/j.ejrs.2016.06.002.

4. Nampak, H.; Pradhan, B.; Manap, M.A. Application of GIS based data driven evidential belief function model to predict groundwater potential zonation. J. Hydrol. 2014, 513, 283-300, doi:10.1016/j.jhydrol.2014.02.053.

5. Ahmad, I.; Dar, M.A.; Andualem, T.G.; Teka, A.H.; Tolosa, A.T. GIS-Based Multi-criteria Evaluation for Deciphering of Groundwater Potential. J. Indian Soc. Remote Sens. 2019, 48, 305-313, doi:10.1007/s12524-019-01078-3.

6. Andualem, T.G.; Demeke, G.G. Groundwater potential assessment using GIS and remote sensing: A case study of Guna tana landscape, upper blue Nile Basin, Ethiopia. J. Hydrol. Reg. Stud. 2019, 24, 100610, doi:10.1016/j.ejrh.2019.100610.

7. Jha, M.K.; Chowdary, V.M.; Kulkarni, Y.; Mal, B.C. Rainwater harvesting planning using geospatial techniques and multicriteria decision analysis. Resour. Conserv. Recycl. 2014, 83, 96-111, doi:10.1016/j.resconrec.2013.12.003.

8. Jha, M.K.; Chowdary, V.M.; Chowdhury, A. Groundwater assessment in Salboni Block, West Bengal (India) using remote sensing, geographical information system and multi-criteria decision analysis techniques. Hydrogeol. J. 2010, 18, 1713-1728, doi:10.1007/s10040-010-0631-z.

9. Ajay Kumar, V.; Mondal, N.C.; Ahmed, S. Identification of Groundwater Potential Zones Using RS, GIS and AHP Techniques: A Case Study in a Part of Deccan Volcanic Province (DVP), Maharashtra, India. J. Indian Soc. Remote Sens. 2020, 48, 497-511, doi:10.1007/s12524-019-01086-3.

10. Qadir, J.; Bhat, M.S.; Alam, A.; Rashid, I. Mapping groundwater potential zones using remote sensing and GIS approach in Jammu Himalaya, Jammu and Kashmir. GeoJournal 2020, 85, 487-504, doi:10.1007/s10708-019-09981-5.

11. Indhulekha, K.; Mondal, K.C.; Jhariya, D.C. Groundwater prospect mapping using remote sensing, GIS and resistivity survey techniques in Chhokra Nala Raipur district, Chhattisgarh, India. J. Water Supply Res. Technol. - AQUA 2019, 68, 595-606, doi:10.2166/aqua.2019.159.

12. Arya, S.; Subramani, T.; Karunanidhi, D. Delineation of groundwater potential zones and recommendation of artificial recharge structures for augmentation of groundwater resources in Vattamalaikarai Basin, South India. Environ. Earth Sci. 2020, 79, doi:10.1007/s12665-020-8832-9.

13. Etikala, B.; Golla, V.; Li, P.; Renati, S. Deciphering groundwater potential zones using MIF technique and GIS: A study from 
Tirupati area, Chittoor District, Andhra Pradesh, India. HydroResearch 2019, 1, 1-7, doi:10.1016/j.hydres.2019.04.001.

14. Maity, D.K.; Mandal, S. Identification of groundwater potential zones of the Kumari river basin, India: an RS \& GIS based semi-quantitative approach. Environ. Dev. Sustain. 2019, 21, 1013-1034, doi:10.1007/s10668-017-0072-0.

15. Nithya, C.N.; Srinivas, Y.; Magesh, N.S.; Kaliraj, S. Assessment of groundwater potential zones in Chittar basin, Southern India using GIS based AHP technique. Remote Sens. Appl. Soc. Environ. 2019, 15, 100248, doi:10.1016/j.rsase.2019.100248.

16. Adeyeye, O.A.; Ikpokonte, E.A.; Arabi, S.A. GIS-based groundwater potential mapping within Dengi area, North Central Nigeria. Egypt. J. Remote Sens. Sp. Sci. 2019, 22, 175-181, doi:10.1016/j.ejrs.2018.04.003.

17. Hettiarachchi, I. A REVIEW ON GROUND WATER MANAGEMENT ISSUES IN THE DRY. BALWOIS 2008, 27-31.

18. Pankaj, K.; Herath, S.; Avtar, R.; Takeuchi, K. Mapping of groundwater potential zones in Killinochi area , Sri Lanka , using GIS and remote sensing techniques. Sustain. Water Resour. Manag. 2016, 2, 419-430, doi:10.1007/s40899-016-0072-5.

19. District Secretariat Kilinochchi Statistical Hand Book-2020; 2020;

20. Amarasinghe, U..; Mutuwatta, L.; Sakthivadive, R. Water Scarcity Variations within a Country: A Case Study of Sri Lanka-Research Report 32; International Water Management Institute, 1999;

21. Senanayake, I.P.; Dissanayake, D.M.D.O.K.; Mayadunna, B.B.; Weerasekera, W.L. An approach to delineate groundwater recharge potential sites in Ambalantota, Sri Lanka using GIS techniques. Geosci. Front. 2016, 7, 115-124, doi:10.1016/j.gsf.2015.03.002.

22. District Secretariat - Kilinochchi Statistical Hand Book-2019 (chapter 01); 2019;

23. Satapathy, I.; Syed, T.H. Characterization of groundwater potential and artificial recharge sites in Bokaro District, Jharkhand (India), using remote sensing and GIS-based techniques. Environ. Earth Sci. 2015, 74, 4215-4232, doi:10.1007/s12665-015-44748.

24. Lu, G.Y.; Wong, D.W. An adaptive inverse-distance weighting spatial interpolation technique. Comput. Geosci. 2008, 34, 10441055, doi:10.1016/j.cageo.2007.07.010.

25. Chen, F.W.; Liu, C.W. Estimation of the spatial rainfall distribution using inverse distance weighting (IDW) in the middle of Taiwan. Paddy Water Environ. 2012, 10, 209-222, doi:10.1007/s10333-012-0319-1.

26. Rajasekhar, M.; Sudarsana Raju, G.; Sreenivasulu, Y.; Siddi Raju, R. Delineation of groundwater potential zones in semi-arid region of Jilledubanderu river basin, Anantapur District, Andhra Pradesh, India using fuzzy logic, AHP and integrated fuzzy-AHP approaches. HydroResearch 2019, 2, 97-108, doi:10.1016/j.hydres.2019.11.006.

27. Chowdhury, A.; Jha, M.K.; Chowdary, V.M. Delineation of groundwater recharge zones and identification of artificial recharge sites in West Medinipur district, West Bengal, using RS, GIS and MCDM techniques. Environ. Earth Sci. 2010, 59, 1209-1222, doi:10.1007/s12665-009-0110-9.

28. Saaty, T.L. The Analytic Hierarchy Process: Planning, Priority Setting, Resources Allocation; New York: Mcgraw-Hill: New York, 1980;

29. Dissanayake, D.; Morimoto, T.; Murayama, Y.; Ranagalage, M.; Perera, E.N.C. Analysis of life quality in a tropical mountain city using a multi-criteria geospatial technique: A case study of Kandy city, Sri Lanka. Sustain. 2020, 12, doi:10.3390/su12072918.

30. Rahmati, O.; Nazari Samani, A.; Mahdavi, M.; Pourghasemi, H.R.; Zeinivand, H. Groundwater potential mapping at Kurdistan region of Iran using analytic hierarchy process and GIS. Arab. J. Geosci. 2015, 8, 7059-7071, doi:10.1007/s12517-0141668-4.

31. Fashae, O.A.; Tijani, M.N.; Talabi, A.O.; Adedeji, O.I. Delineation of groundwater potential zones in the crystalline basement terrain of SW-Nigeria: an integrated GIS and remote sensing approach. Appl. Water Sci. 2014, 4, 19-38, doi:10.1007/s13201013-0127-9.

32. Kumar, T.; Gautam, A.K.; Kumar, T. Appraising the accuracy of GIS-based Multi-criteria decision making technique for delineation of Groundwater potential zones. Water Resour. Manag. 2014, 28, 4449-4466, doi:10.1007/s11269-014-0663-6. 
33. Bhunia, G.S. An approach to demarcate groundwater recharge potential zone using geospatial technology. Appl. Water Sci. 2020, 10, 1-12, doi:10.1007/s13201-020-01231-1.

34. Krishnamurthy, J.; Srinivas, G. Role of geological and geomorphological factors in ground water exploration: A study using irs liss data. Int. J. Remote Sens. 1995, 16, 2595-2618, doi:10.1080/01431169508954579.

35. Chakrabortty, R.; Pal, S.C.; Malik, S.; Das, B. Modeling and mapping of groundwater potentiality zones using AHP and GIS technique: a case study of Raniganj Block, Paschim Bardhaman, West Bengal. Model. Earth Syst. Environ. 2018, 4, 1085-1110, doi:10.1007/s40808-018-0471-8.

36. Guru, B.; Seshan, K.; Bera, S. Frequency ratio model for groundwater potential mapping and its sustainable management in cold desert, India. J. King Saud Univ. - Sci. 2017, 29, 333-347, doi:10.1016/j.jksus.2016.08.003.

37. Senarathne, S.L.; Jayawardana, J.M.C.K.; Edirisinghe, E.A.N.V.; Chandrajith, R. Characterization of groundwater in Malala oya river basin, Sri Lanka using geochemical and isotope signatures. Groundw. Sustain. Dev. 2019, 9, 100225, doi:10.1016/j.gsd.2019.100225.

38. Harini, P.; Sahadevan, D.K.; Das, I.C.; Manikyamba, C.; Durgaprasad, M.; Nandan, M.J. Regional Groundwater Assessment of Krishna River Basin Using Integrated GIS Approach. J. Indian Soc. Remote Sens. 2018, 46, 1365-1377, doi:10.1007/s12524018-0780-4.

39. Jasrotia, A.S.; Majhi, A.; Singh, S. Water balance approach for rainwater harvesting using remote sensing and GIS techniques, Jammu Himalaya, India. Water Resour. Manag. 2009, 23, 3035-3055, doi:10.1007/s11269-009-9422-5.

40. Magesh, N.S.; Chandrasekar, N.; Soundranayagam, J.P. Delineation of groundwater potential zones in Theni district, Tamil Nadu, using remote sensing, GIS and MIF techniques. Geosci. Front. 2012, 3, 189-196, doi:10.1016/j.gsf.2011.10.007.

41. Varade, A.M.; Khare, Y.D.; Yadav, P.; Doad, A.P.; Das, S.; Kanetkar, M.; Golekar, R.B. 'Lineaments' the Potential Groundwater Zones in Hard Rock Area: A Case Study of Basaltic Terrain of WGKKC-2 Watershed from Kalmeswar Tehsil of Nagpur District, Central India. J. Indian Soc. Remote Sens. 2018, 46, 539-549, doi:10.1007/s12524-017-0716-4.

42. Anderson, G.B.; Barnes, E.A.; Bell, M.L.; Dominici, F. The future of climate epidemiology: Opportunities for advancing health research in the context of climate change. Am. J. Epidemologylogy 2019, 80523, 1-32.

43. Saha, S. Groundwater potential mapping using analytical hierarchical process: a study on Md. Bazar Block of Birbhum District, West Bengal. Spat. Inf. Res. 2017, 25, 615-626, doi:10.1007/s41324-017-0127-1.

44. Abdelrahman, M.A.E.; Natarajan, A.; Hegde, R. Assessment of land suitability and capability by integrating remote sensing and GIS for agriculture in Chamarajanagar district, Karnataka, India. Egypt. J. Remote Sens. Sp. Sci. 2016, 19, 125-141, doi:10.1016/j.ejrs.2016.02.001. 